\title{
Article
}

\section{The Association between Diabetes Mellitus and Keratoplasty in Poland in the Years 2013-2017}

\author{
Milena Kozioł ${ }^{1,2}$, Michał Szymon Nowak ${ }^{3,4, * \mathbb{C}}$, Monika Udziela ${ }^{2}$ and Jacek Paweł Szaflik ${ }^{2}$ \\ 1 Department of Analyses and Strategies, Ministry of Health, 00-952 Warsaw, Poland; m.koziol@mz.gov.pl \\ 2 Department of Ophthalmology, Public Ophthalmic Clinical Hospital (SPKSO), Medical University of Warsaw, \\ 03-709 Warsaw, Poland; monika.udziela@wum.edu.pl (M.U.); szaflik@okulistyka.eu (J.P.S.) \\ 3 Provisus Eye Clinic, 42-209 Czestochowa, Poland \\ 4 Saint Family Hospital Medical Center, 90-302 Lodz, Poland \\ * Correspondence: michaelnovak@interia.pl
}

Citation: Kozioł, M.; Nowak, M.S.;

Udziela, M.; Szaflik, J.P. The

Association between Diabetes

Mellitus and Keratoplasty in Poland in the Years 2013-2017. Int. J. Environ. Res. Public Health 2021, 18, 9767. https://doi.org/10.3390/ijerph 18189767

Academic Editor: Emanuela Orsi

Received: 12 July 2021

Accepted: 13 September 2021

Published: 16 September 2021

Publisher's Note: MDPI stays neutral with regard to jurisdictional claims in published maps and institutional affiliations.

Copyright: (c) 2021 by the authors. Licensee MDPI, Basel, Switzerland. This article is an open access article distributed under the terms and conditions of the Creative Commons Attribution (CC BY) license (https:// creativecommons.org/licenses/by/ $4.0 /)$.
Abstract: Background: The aim of this study is to assess the incidence and characteristic of corneal grafts and its association with diabetes mellitus in Poland in the years 2013-2017. Methods: The retrospective survey of the National Database of Hospitalizations was performed to identify all the corneal transplantations in Poland between January 2013 and December 2017. The comorbid diseases, in particular diabetes mellitus, were verified in the patients' medical history. The logistic regression was applied to demonstrate the factors related to urgent surgeries. Results: In total, 5069 corneal grafts in 4710 patients were reported in the years 2013-2017. The number of CTs gradually increased by 37\% from 914 (2.37 surgeries per one hundred thousand population) in the year 2013 to 1250 (3.25 surgeries per one hundred thousand population) in 2017, the final year of the study. CT incidence was the highest in subjects aged 70 years or older: 13.18 per one hundred thousand population in the year 2017. On average, about $22.43 \%$ of procedures were performed in patients with DM. The chance of urgent surgery was mostly correlated with full thickness CT and patients' age. Conclusions: Despite the relatively low value of CT in Poland, there was an increasing number of CTs in the analyzed period.

Keywords: corneal transplantation; diabetes mellitus; urgent surgery

\section{Introduction}

After cataract and glaucoma, corneal blindness is the third leading cause of blindness worldwide [1]. The prevalence of corneal blindness varies from country to country, depending on numerous factors, such as availability and general standards of eye care [2]. For instance, in some areas of Africa, even $90 \%$ of all blindness directly results from corneal pathology [3]. Unfortunately, in many cases, corneal transplantation (CT) is the only way to restore visual function when impairment caused by corneal damage results in an unacceptable quality of life [4]. A Global Survey of Corneal Transplantation and Eye Banking conducted in 2016, covering more than $95 \%$ of the world's population, revealed a severe imbalance between the supply and demand for CT. Even though corneal transplantation is the most frequently performed type of transplant surgery worldwide, about $50 \%$ of the population has no access to it [5]. With an estimated 12.7 million people waiting for corneal transplantation in 2012, 1 in 70 of the needs are met worldwide. In Poland, corneal transplantation has been performed since 1926. CT is allowed only in public hospitals and is reimbursed entirely from public funds by the National Health Fund (NHF). Moreover, there are seven eye banks that are the only transplantation facilities to provide cornea tissue. In Poland, there is a shortage of donor corneas compared to recipients, which results in a long waiting time for corneal transplantation [6].

A systematic review shows that healthcare analysis often refers to comorbid factors that explain medical and systemic relations [7-9]. Several approaches have been developed 
to define the comorbid variables. One of the most popular methodologies has been proposed by Elixhauser et al. and it includes 30 comorbid factors. Among those factors, diabetes mellitus (DM) is a significant condition for the probability of death, hospital stay, and medical expenditure [10]. In terms of ocular disorders, DM is considered to be a serious condition that could affect the quality of vision and be an important risk factor for postoperative complications [11-14].

The primary aim of the present study is to analyze the incidence of corneal grafts and information related to the type of surgery, medical indications, and association with DM in Poland, during the period of 2013-2017. The secondary aim is to analyze the occurrence of comorbid factors (including DM) among graft recipients who had been waiting for corneal transplantations in Poland during 2013-2017.

\section{Material and methods}

\subsection{Data Sources, Disease Codes, and Definitions}

The present study was co-financed by the European Union funds through the European Social Fund under the Operational Program of Knowledge, Education, and Development and was a part of the Polish Ministry of Health project "Maps of Healthcare Needs —Database of Systemic and Implementation Analyses" [15-17].

The study design was a retrospective population-based survey. Assessed data from all patients who underwent CT in Poland between January 2013 and December 2017 were obtained from the national database of medical services [18]. In Poland, information related to all levels of healthcare services at public and private institutions financed from public sources is recorded in the database of the NHF. The information includes personal identification number (PESEL), medical data, and demography (date of birth, area code, sex of patients). The medical data include diagnoses coded according to the International Classification of Diseases, 10th Revision, and all performed procedures coded using the International Classification of Diseases, 9th Revision, ICD-9 procedure codes and unique NHF codes corresponding to certain hospital procedures. The population data about Poland were obtained from Central Statistical Office of Poland [19]. To define CT, the following NHF codes were used: B06, B07, and B08. The ICD-9 codes 11.63 and 11.64 were used to identify penetrating keratoplasty, and the ICD-9 codes 11.61 and 11.62 were used to identify lamellar keratoplasty. Keratoplasty was also considered with additional reported procedures (recognized with ICD-9 codes): $14.73,14.74$, and 14.75 corresponding to CT combined with vitrectomy; 12.59 and 12.69 corresponding to CT followed by glaucoma filtration surgery, and 13.71 corresponding to CT combined with cataract surgery. CTs reported in the years 2013-2017 were taken into consideration. The indications for CT were identified with ICD-10 codes reported to NHF after surgery, including ocular surface disease (H18.8), bullous keratopathy (H18.1), infectious keratitis and corneal ulcers (H16.0, H16.2, H16.3, H16.8, H16.9), keratoconus (H18.6), leucoma and corneal scars (H17.8, H17.9, H17.1), corneal pigmentations and deposits (H18.0), corneal dystrophies such as Fuchs's dystrophy (H18.5), and band keratopathy (H18.4) — presented in Appendix A.

During the study period, in the years 2013-2017, each patient reported in the NHF database with type 1 or type 2 diabetes mellitus (DM) was retrospectively identified with ICD-10 codes E10 and E11. If a patient had two different diagnoses, the more common ICD10 code was taken into account. All diagnoses were then confirmed if a patient purchased antidiabetic drugs (and/or insulin) within the period of the study. Patients with the ICD-10 codes E12, E13, and E14 were excluded from the analysis.

The investigation of comorbid diseases among patients who had been waiting for CT required access to the data collected by Poltransplant—an institution responsible for the transplantation process in Poland. Each patient who was active for at least one day on the waiting list for CT in the Poltransplant database was included in the study. Personal National identification number (PESEL) allowed the Poltransplant records to be merged with NHF data in order to verify the 2-year medical history of each patient. Medical history was described by 30 variables defined by ICD-10 codes presented in Appendix B. 


\subsection{Statistical Analysis}

Statistical analyses included the descriptive statistics of corneal graft incidence in the years 2013-2017 in Poland matched with the general Polish population and the patients medical and demographical features. In addition, the occurrence of comorbid diseases (including DM) among persons who waited for CT in the years 2013-2017 has been verified. A logistic regression model has been built to evaluate the factors correlated with urgent admission to hospital for CT in Poland during 2013-2017. The independent variable had a binary distribution (1-urgent, 0 - elective surgery). The results of model estimation were presented in terms of odds ratio (OR) with a $95 \%$ confidence interval (CI). The significance of parameter estimation was validated with a $p$-value $<0.05$. R statistical software V. 3.5.2 was used for all analyses.

The study adhered to the tenets of the Declaration of Helsinki for research involving human subjects and the study protocol was approved by the Polish Ministry of Health, which is authorized by the law of the Republic of Poland to process the National Health Fund data.

\section{Results}

In total, 5069 corneal transplantations in 4710 patients were reported in Poland during 2013-2017 (Figure 1, Tables 1 and 2). The number of CTs gradually increased from 914 (2.37 surgeries per one hundred thousand population) in the year 2013 to 1250 (3.25 surgeries per one hundred thousand population) in 2017, the final year of the study. CT incidence was the highest in subjects aged 70 years or older: 13.18 per one hundred thousand population in the year 2017. On average, about $22.43 \%$ of the procedures were performed in patients with DM. The demographic characteristics of all the patients who underwent CT showed that $49.15 \%$ of the group were male, the mean age of the study subjects at the time of CT was $61.63 \pm 19.20$ years, and $69.94 \%$ of them lived or had lived in urban areas. The indications for corneal grafts in Poland in the years 2013-2017 are presented in Figure 2 and Table 3. The most frequent indications reported to the NHF database were ocular surface disease (38.51\%), followed by bullous keratopathy $(13.53 \%)$, infectious keratitis, and corneal ulcers (12.23\%). Among the persons with DM who underwent CT in Poland during 2013-2017, ocular surface disease was the most common indication for $\mathrm{CT}$, present in 39.18 and $41.77 \%$ of patients with type $2 \mathrm{DM}$ and type $1 \mathrm{DM}$, respectively. The clinical characteristics of corneal grafts in Poland are presented in Table 4, Figures 3 and 4 . During the study period, $19.55 \%$ of CTs were related to fullthickness and $80.45 \%$ of CTs were related to lamellar corneal grafts in Poland. This ratio was stable over the years 2013-2017. Twenty-one percent of all the CTs were combined with other ophthalmic procedures, including $997(19.39 \%)$ combined with cataract surgery, $27(0.52 \%)$ combined with glaucoma surgery, and $74(1.44 \%)$ with pars plana vitrectomy (PPV), respectively.

The logistic regression model showed (Table 5) that full-thickness corneal graft was a significant factor correlated with urgent admission $(\mathrm{OR}=11.54$, lamellar corneal grafts were a reference group). In comparison with the patients aged $0-18$, the odds ratios for all the other age groups were reduced and statistically significant. In addition, information about CT combined with other ophthalmic procedures occurred as an important variable in the model. The chance of urgent admission in that group was $18 \%$ lower compared to the reference group. The DM, sex, and residence factors did not significantly influence urgent hospital admission for CT. The ROC of the presented model was 0.7. 
Table 1. Incidence of corneal grafts in Poland during 2013-2017.

\begin{tabular}{|c|c|c|c|c|c|c|}
\hline & 2013 & 2014 & 2015 & 2016 & 2017 & $\begin{array}{c}\text { All } \\
\text { (Average) }\end{array}$ \\
\hline Age 0-18 & $7,431,731$ & $7,367,066$ & $7,309,001$ & $7,286,480$ & $7,299,996$ & $7,338,855$ \\
\hline DM in the subgroup, $\%$ & $0.18 \%$ & $0.19 \%$ & $0.20 \%$ & $0.21 \%$ & $0.22 \%$ & $0.20 \%$ \\
\hline No. of corneal grafts & 27 & 33 & 17 & 35 & 18 & 130 \\
\hline Incidence $/ 100,000$ person-yrs & 0.36 & 0.45 & 0.23 & 0.48 & 0.25 & 0.35 \\
\hline DM, \% & $0.00 \%$ & $0.00 \%$ & $0.00 \%$ & $2.86 \%$ & $0.00 \%$ & $0.57 \%$ \\
\hline Age 19-39 & $12,355,235$ & $12,201,430$ & $12,015,345$ & $11,799,562$ & $11,570,164$ & $11,988,347$ \\
\hline $\mathrm{DM}$ in the subgroup, $\%$ & $0.58 \%$ & $0.68 \%$ & $0.79 \%$ & $0.90 \%$ & $1.01 \%$ & $0.79 \%$ \\
\hline fNo. of corneal grafts & 124 & 106 & 117 & 167 & 164 & 678 \\
\hline Incidence $/ 100,000$ person-yrs & 1.00 & 0.87 & 0.97 & 1.42 & 1.42 & 1.14 \\
\hline DM, \% & $4.03 \%$ & $4.72 \%$ & $1.71 \%$ & $1.20 \%$ & $1.83 \%$ & $2.70 \%$ \\
\hline Age 40-49 & $4,879,816$ & $4,956,005$ & $5,064,587$ & $5,202,444$ & $5,341,530$ & $5,088,876$ \\
\hline DM in the subgroup, $\%$ & $2.14 \%$ & $2.30 \%$ & $2.45 \%$ & $2.59 \%$ & $2.70 \%$ & $2.44 \%$ \\
\hline No. of corneal grafts & 85 & 75 & 80 & 95 & 110 & 445 \\
\hline Incidence $/ 100,000$ person-yrs & 1.74 & 1.51 & 1.58 & 1.83 & 2.06 & 1.74 \\
\hline DM, \% & $10.59 \%$ & $8.00 \%$ & $7.50 \%$ & $16.84 \%$ & $7.27 \%$ & $10.04 \%$ \\
\hline Age 50-59 & $5,536,118$ & $5,406,320$ & $5,245,352$ & $5,089,290$ & $4,928,276$ & $5,241,071$ \\
\hline $\mathrm{DM}$ in the subgroup, $\%$ & $6.87 \%$ & $7.16 \%$ & $7.38 \%$ & $7.57 \%$ & $7.68 \%$ & $7.33 \%$ \\
\hline No. of corneal grafts & 138 & 139 & 107 & 137 & 143 & 664 \\
\hline Incidence $/ 100,000$ person-yrs & 2.49 & 2.57 & 2.04 & 2.69 & 2.90 & 2.54 \\
\hline DM, \% & $15.22 \%$ & $15.83 \%$ & $10.28 \%$ & $10.22 \%$ & $9.79 \%$ & $12.27 \%$ \\
\hline Age $60-69$ & $4,409,809$ & $4,642,821$ & $4,888,294$ & $5,024,702$ & $5,127,315$ & $4,818,588$ \\
\hline DM in the subgroup, $\%$ & $15.53 \%$ & $16.20 \%$ & $16.76 \%$ & $17.15 \%$ & $17.34 \%$ & $16.60 \%$ \\
\hline No. of corneal grafts & 157 & 196 & 168 & 228 & 266 & 1015 \\
\hline Incidence $/ 100,000$ person-yrs & 3.56 & 4.22 & 3.44 & 4.54 & 5.19 & 4.19 \\
\hline DM, \% & $35.67 \%$ & $26.02 \%$ & $36.31 \%$ & $25.88 \%$ & $24.06 \%$ & $29.59 \%$ \\
\hline Age 70+ & $3,882,950$ & $3,904,960$ & $3,914,660$ & $4,030,514$ & $4,166,277$ & $3,979,872$ \\
\hline $\mathrm{DM}$ in the subgroup, $\%$ & $21.41 \%$ & $22.88 \%$ & $24.15 \%$ & $25.27 \%$ & $26.17 \%$ & $23.98 \%$ \\
\hline No. of corneal grafts & 383 & 370 & 356 & 479 & 549 & 2137 \\
\hline Incidence $/ 100,000$ person-yrs & 9.86 & 9.48 & 9.09 & 11.88 & 13.18 & 10.70 \\
\hline DM, \% & $31.85 \%$ & $32.16 \%$ & $35.39 \%$ & $33.19 \%$ & $30.24 \%$ & $32.57 \%$ \\
\hline All & $38,495,659$ & $38,478,602$ & $38,437,239$ & $38,432,992$ & $38,433,558$ & $38,455,610$ \\
\hline $\mathrm{DM}$ in the subgroup, $\%$ & $5.42 \%$ & $5.83 \%$ & $6.20 \%$ & $6.56 \%$ & $6.86 \%$ & $6.17 \%$ \\
\hline No. of corneal grafts & 914 & 919 & 845 & 1141 & 1250 & 5069 \\
\hline Incidence $/ 100,000$ person-yrs & 2.37 & 2.39 & 2.20 & 2.97 & 3.25 & 2.64 \\
\hline $\mathrm{DM}, \%$ & $23.30 \%$ & $22.09 \%$ & $24.38 \%$ & $22.00 \%$ & $20.40 \%$ & $22.43 \%$ \\
\hline
\end{tabular}

Table 2. Demographic characteristics of patients with corneal grafts in Poland during 2013-2017.

\begin{tabular}{ccccccc}
\hline & $\mathbf{2 0 1 3}$ & $\mathbf{2 0 1 4}$ & $\mathbf{2 0 1 5}$ & $\mathbf{2 0 1 6}$ & $\mathbf{2 0 1 7}$ & All \\
\hline Mean age \pm SE & $60.99 \pm 19.45$ & $61 \pm 18.8$ & $61.25 \pm 19.32$ & $61.29 \pm 20.04$ & $63.15 \pm 18.4$ & $61.63 \pm 19.2$ \\
\hline Women (\%) & $426(49.71 \%)$ & $412(47.96 \%)$ & $388(49.87 \%)$ & $554(52.31 \%)$ & $615(53.15 \%)$ & $2395(50.85 \%)$ \\
\hline Men (\%) & $431(50.29 \%)$ & $447(52.04 \%)$ & $390(50.13 \%)$ & $505(47.69 \%)$ & $542(46.85 \%)$ & $2315(49.15 \%)$ \\
\hline $\begin{array}{c}\text { Urban } \\
\text { residence (\%) }\end{array}$ & $612(71.41 \%)$ & $600(69.85 \%)$ & $550(70.69 \%)$ & $740(69.88 \%)$ & $792(68.45 \%)$ & $3294(69.94 \%)$ \\
\hline $\begin{array}{c}\text { Rural } \\
\text { Residence }(\%)\end{array}$ & $245(28.59 \%)$ & $259(30.15 \%)$ & $228(29.31 \%)$ & $319(30.12 \%)$ & $365(31.55 \%)$ & $1416(30.06 \%)$ \\
\hline
\end{tabular}




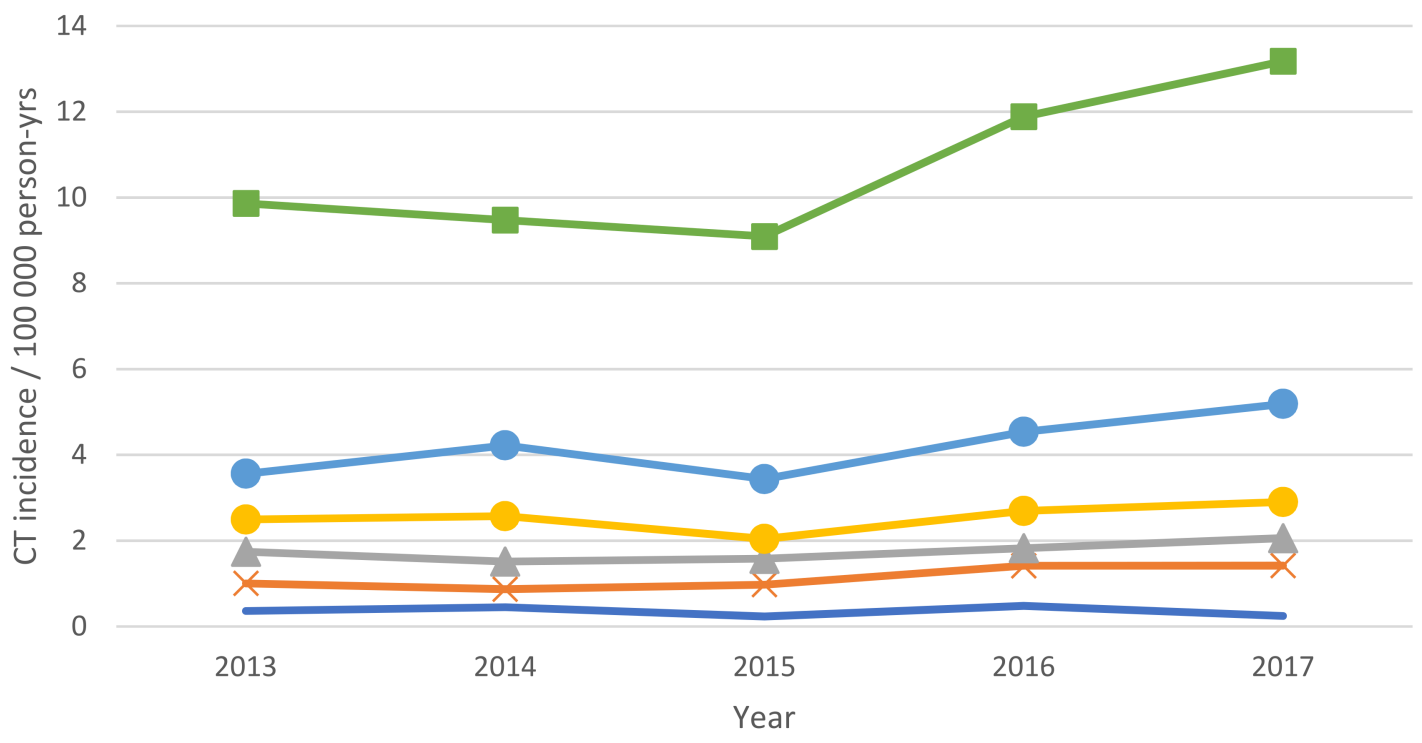

- Age 0-18

$\simeq$ Age 19-39

$\longrightarrow$ Age 40-49

-Age 50-59

-Age 60-69

- Age 70+

Figure 1. Incidence of corneal grafts in age groups in Poland during 2013-2017.

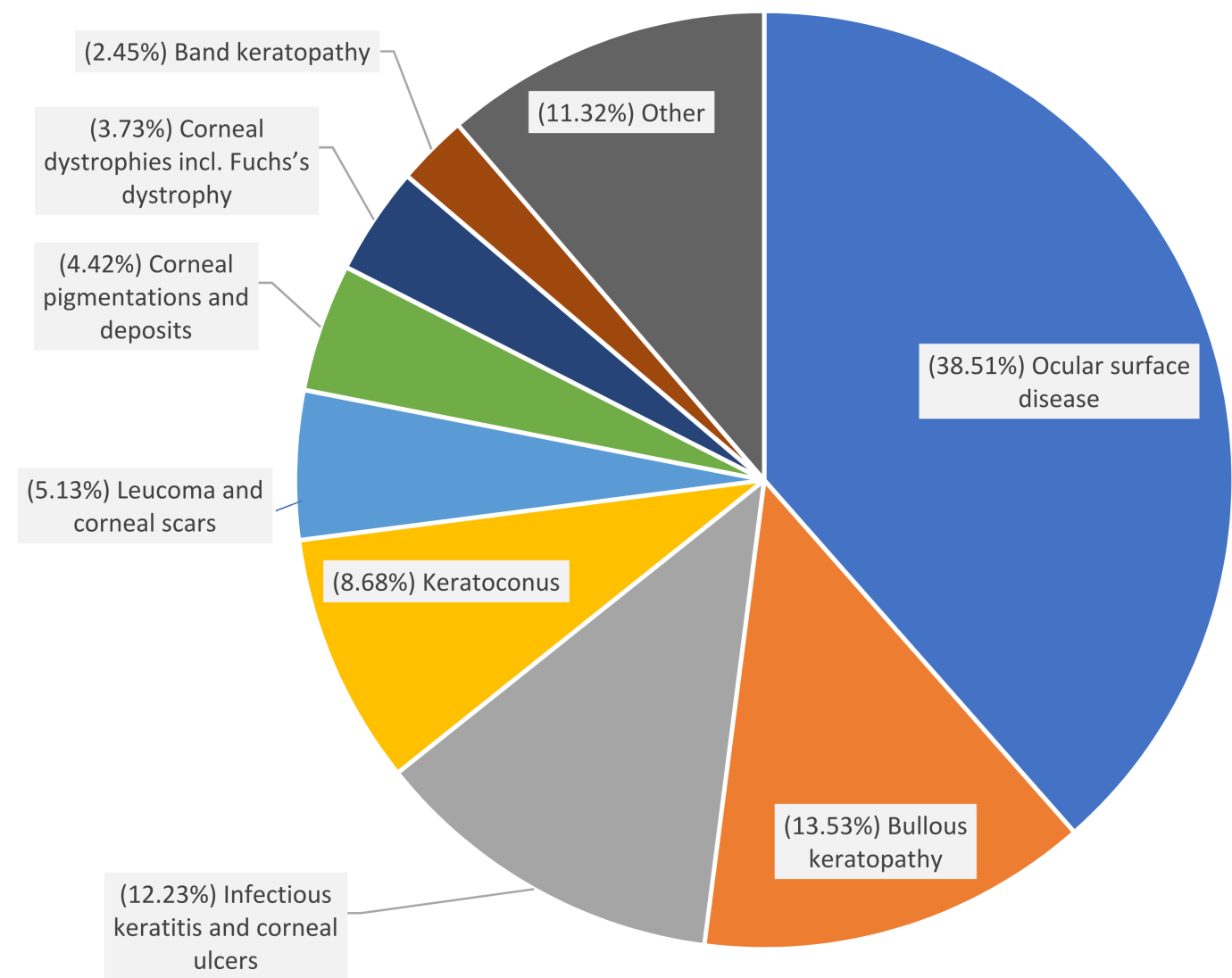

Figure 2. Indications for corneal grafts in Poland in the years 2013-2017. 


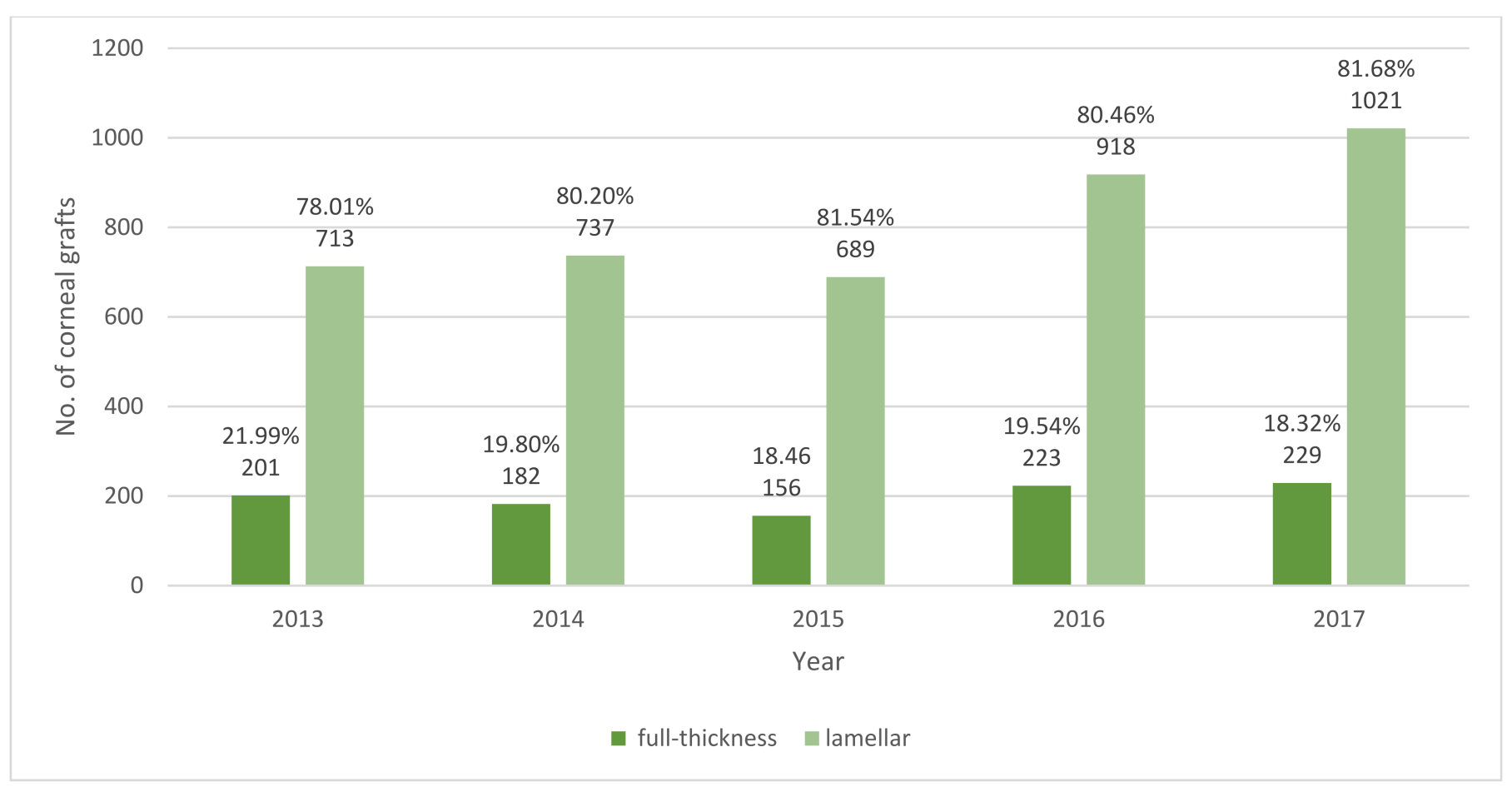

Figure 3. Number of full thickness and lamellar corneal grafts in Poland during 2013-2017.

Table 3. Indications for corneal grafts in Poland in the years 2013-2017.

\begin{tabular}{|c|c|c|c|c|c|}
\hline Indication & $\begin{array}{l}\text { No. of Corneal } \\
\text { Grafts 2013-2017 } \\
\text { (\% of all) }\end{array}$ & $\begin{array}{l}\text { No. of Subjects } \\
\text { with Corneal } \\
\text { Grafts and Type } 1 \\
\text { DM (\% of All) }\end{array}$ & $\begin{array}{l}\text { No. of Subjects } \\
\text { with Corneal } \\
\text { Grafts and Type } 2 \\
\text { DM (\% of All) }\end{array}$ & $\begin{array}{c}\text { No. of } \\
\text { Full-Thickness } \\
\text { Corneal Grafts } \\
\text { 2013-2017 (\% of All) }\end{array}$ & $\begin{array}{c}\text { No. of } \\
\text { Partial-Corneal } \\
\text { Grafts 2013-2017 } \\
\text { (\% of All) }\end{array}$ \\
\hline Ocular surface disease & $\begin{array}{c}1952 \\
(38.51 \%)\end{array}$ & $\begin{array}{c}33 \\
(41.77 \%)\end{array}$ & $\begin{array}{c}411 \\
(39.18 \%)\end{array}$ & $\begin{array}{c}1707 \\
(41.86 \%)\end{array}$ & $\begin{array}{c}245 \\
(24.72 \%)\end{array}$ \\
\hline Bullous keratopathy & $\begin{array}{c}686 \\
(13.53 \%)\end{array}$ & $\begin{array}{c}9 \\
(11.39 \%)\end{array}$ & $\begin{array}{c}182 \\
(17.35 \%)\end{array}$ & $\begin{array}{c}386 \\
(9.47 \%)\end{array}$ & $\begin{array}{c}300 \\
(30.27 \%)\end{array}$ \\
\hline $\begin{array}{l}\text { Infectious keratitis and } \\
\text { corneal ulcers }\end{array}$ & $\begin{array}{c}620 \\
(12.23 \%)\end{array}$ & $\begin{array}{c}19 \\
(24.05 \%)\end{array}$ & $\begin{array}{c}131 \\
(12.49 \%)\end{array}$ & $\begin{array}{c}591 \\
(14.49 \%)\end{array}$ & $\begin{array}{c}29 \\
(2.93 \%)\end{array}$ \\
\hline Keratoconus & $\begin{array}{c}440 \\
(8.68 \%)\end{array}$ & $\begin{array}{c}1 \\
(1.27 \%)\end{array}$ & $\begin{array}{c}21 \\
(2.00 \%)\end{array}$ & $\begin{array}{c}386 \\
(9.47 \%)\end{array}$ & $\begin{array}{c}54 \\
(5.45 \%)\end{array}$ \\
\hline Leucoma and corneal scars & $\begin{array}{c}260 \\
(5.13 \%)\end{array}$ & $\begin{array}{c}3 \\
(3.80 \%)\end{array}$ & $\begin{array}{c}53 \\
(5.05 \%)\end{array}$ & $\begin{array}{c}242 \\
(5.93 \%)\end{array}$ & $\begin{array}{c}18 \\
(1.82 \%)\end{array}$ \\
\hline $\begin{array}{l}\text { Corneal pigmentations and } \\
\text { deposits }\end{array}$ & $\begin{array}{c}224 \\
(4.42 \%)\end{array}$ & $\begin{array}{c}0 \\
(0.00 \%)\end{array}$ & $\begin{array}{c}59 \\
(5.62 \%)\end{array}$ & $\begin{array}{c}194 \\
(4.76 \%)\end{array}$ & $\begin{array}{c}30 \\
(3.03 \%)\end{array}$ \\
\hline $\begin{array}{l}\text { Corneal dystrophies incl. } \\
\text { Fuchs's dystrophy }\end{array}$ & $\begin{array}{c}189 \\
(3.73 \%)\end{array}$ & $\begin{array}{c}2 \\
(2.53 \%)\end{array}$ & $\begin{array}{c}38 \\
(3.62 \%)\end{array}$ & $\begin{array}{c}39 \\
(0.96 \%)\end{array}$ & $\begin{array}{c}150 \\
(15.14 \%)\end{array}$ \\
\hline Band keratopathy & $\begin{array}{c}124 \\
(2.45 \%)\end{array}$ & $\begin{array}{c}2 \\
(2.53 \%)\end{array}$ & $\begin{array}{c}26 \\
(2.48 \%)\end{array}$ & $\begin{array}{c}80 \\
(1.96 \%)\end{array}$ & $\begin{array}{c}44 \\
(4.44 \%)\end{array}$ \\
\hline Other & $\begin{array}{c}574 \\
(11.32 \%)\end{array}$ & $\begin{array}{c}10 \\
(12.66 \%)\end{array}$ & $\begin{array}{c}128 \\
(12.20 \%)\end{array}$ & $\begin{array}{c}453 \\
(11.11 \%)\end{array}$ & $\begin{array}{c}121 \\
(12.21 \%)\end{array}$ \\
\hline All & $\begin{array}{c}5069 \\
(100 \%)\end{array}$ & $\begin{array}{c}79 \\
(100 \%)\end{array}$ & $\begin{array}{c}1049 \\
(100 \%)\end{array}$ & $\begin{array}{c}991 \\
(100 \%)\end{array}$ & $\begin{array}{c}4078 \\
(100 \%)\end{array}$ \\
\hline
\end{tabular}


Table 4. Clinical characteristics of corneal grafts in Poland from 2013 to 2017.

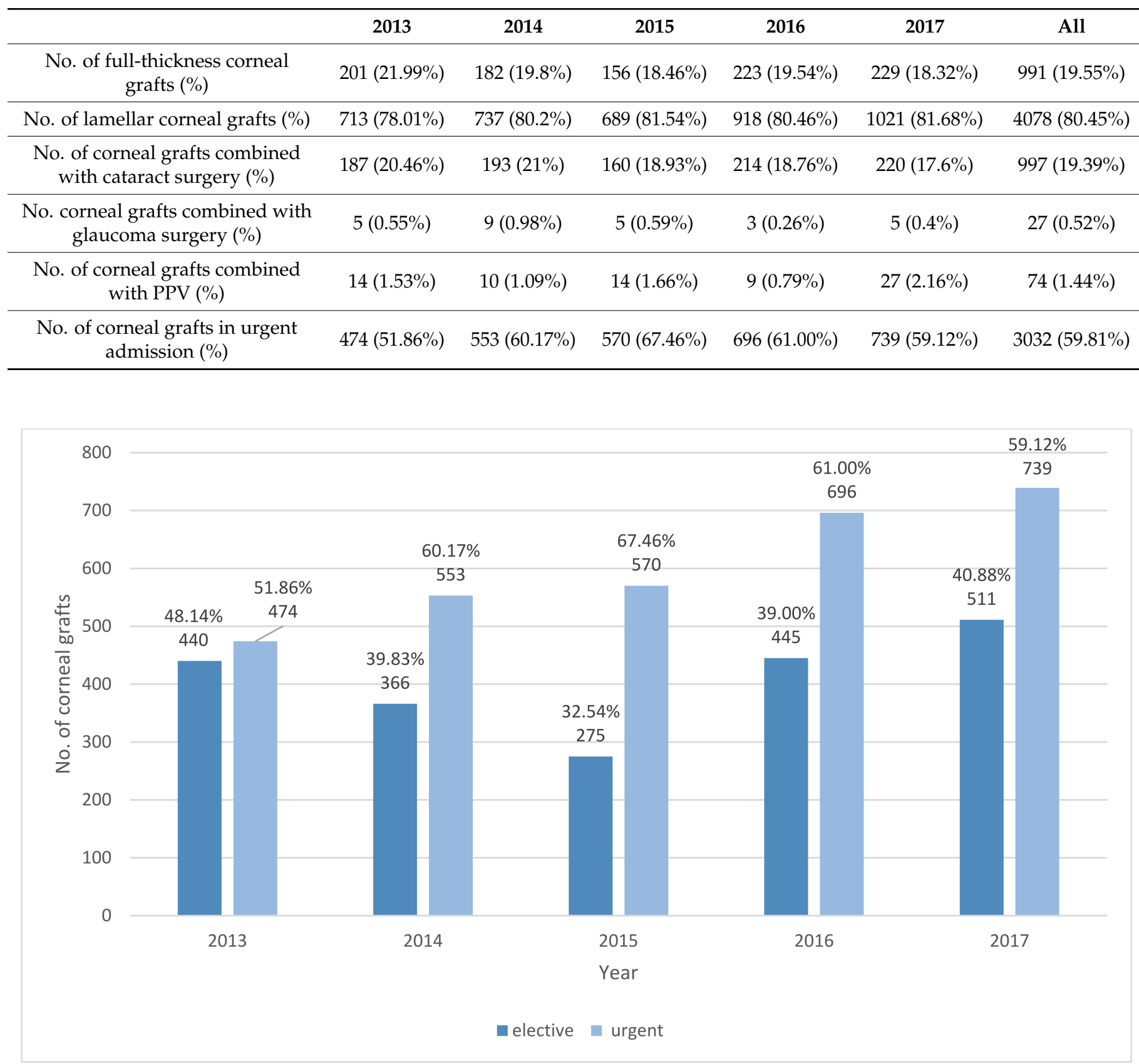

Figure 4. Number of elective and urgent corneal grafts in Poland during 2013-2017.

Table 6 demonstrates the characteristics of the population waiting for CT in terms of comorbid factors in the years 2013-2017 in Poland. The selected variables defined by the occurrence of suitable ICD-10 codes in the medical history of the patients accurately describe the general health condition of the persons waiting for CT. It turns out that $19.63 \%$ of the group were reported with type $2 \mathrm{DM}$ and $1.31 \%$ with type $1 \mathrm{DM}$. That implies that the prevalence of DM in the group was about three times higher than in the general population. 
Table 5. A logistic regression model evaluating the factors correlated with urgent vs. elective CT in Poland during 2013-2017.

\begin{tabular}{|c|c|c|c|}
\hline & OR & $95 \%$ CI & $p$-Value \\
\hline DM type (no) & reference & & \\
\hline Type 1 DM & 1.01 & $(0.63 ; 1.64)$ & 0.976 \\
\hline Type 2 DM & 1.05 & $(0.9 ; 1.23)$ & 0.498 \\
\hline Type-partial & reference & & \\
\hline Type-full & 11.54 & $(10.08 ; 18.58)$ & $0.000 *$ \\
\hline Age $0-18$ & reference & & \\
\hline Age 19-39 & 0.45 & $(0.27 ; 0.72)$ & 0.001 * \\
\hline Age $40-49$ & 0.49 & $(0.29 ; 0.79)$ & $0.004 *$ \\
\hline Age 50-59 & 0.49 & $(0.3 ; 0.78)$ & 0.004 * \\
\hline Age 60-69 & 0.44 & $(0.27 ; 0.69)$ & 0.001 * \\
\hline Age $70+$ & 0.35 & $(0.21 ; 0.54)$ & $0.000 *$ \\
\hline Combined (no) & reference & & \\
\hline Combined (yes) & 0.82 & $(0.70 ; 0.96)$ & 0.011 * \\
\hline Sex (man) & reference & & \\
\hline Sex (woman) & 1 & $(0.88 ; 1.13)$ & 0.959 \\
\hline Residence (rural) & reference & & \\
\hline Residence (urban) & 0.91 & $(0.8 ; 1.04)$ & 0.168 \\
\hline
\end{tabular}

Table 6. Characteristics of the population waiting for keratoplasty in terms of comorbid factors in the years 2013-2017 in Poland.

\begin{tabular}{|c|c|c|c|}
\hline Comorbidity Variable & $\begin{array}{l}\text { No. of People on the } \\
\text { Waiting List }\end{array}$ & Comorbidity Variable & $\begin{array}{l}\text { No. of People on the } \\
\text { Waiting List }\end{array}$ \\
\hline Age & $62.05 \pm 19.00$ & Fluid and electrolyte disorders & $\begin{array}{c}176 \\
(2.22 \%)\end{array}$ \\
\hline Sex (women) & $\begin{array}{c}4144 \\
(52.30 \%)\end{array}$ & AIDS/HIV & $\begin{array}{c}0 \\
(0.00 \%)\end{array}$ \\
\hline Urban & $\begin{array}{c}5466 \\
(69.10 \%)\end{array}$ & Hypothyroidism & $\begin{array}{c}809 \\
(10.21 \%)\end{array}$ \\
\hline Alcohol abuse & $\begin{array}{c}206 \\
(2.60 \%)\end{array}$ & Hypertension & $\begin{array}{c}4770 \\
(60.21 \%)\end{array}$ \\
\hline Blood loss anaemia & $\begin{array}{c}21 \\
(0.27 \%)\end{array}$ & Liver disease & $\begin{array}{c}220 \\
(2.78 \%)\end{array}$ \\
\hline Arrhythmias & $\begin{array}{c}1436 \\
(18.13 \%)\end{array}$ & Lymphoma & $\begin{array}{c}42 \\
(0.53 \%)\end{array}$ \\
\hline $\begin{array}{l}\text { Solid tumor without } \\
\text { metastasis }\end{array}$ & $\begin{array}{c}654 \\
(8.26 \%)\end{array}$ & Metastatic cancer & $\begin{array}{c}53 \\
(0.67 \%)\end{array}$ \\
\hline Congestive heart failure & $\begin{array}{c}1297 \\
(16.37 \%)\end{array}$ & Other neurological disorders & $\begin{array}{c}352 \\
(4.44 \%)\end{array}$ \\
\hline Coagulopathy & $\begin{array}{c}76 \\
(0.96 \%)\end{array}$ & Obesity & $\begin{array}{c}210 \\
(2.65 \%)\end{array}$ \\
\hline Chronic pulmonary disease & $\begin{array}{c}1241 \\
(15.67 \%)\end{array}$ & Paralysis & $\begin{array}{c}69 \\
(0.87 \%)\end{array}$ \\
\hline
\end{tabular}


Table 6. Cont.

\begin{tabular}{|c|c|c|c|}
\hline Comorbidity Variable & $\begin{array}{l}\text { No. of People on the } \\
\text { Waiting List }\end{array}$ & Comorbidity Variable & $\begin{array}{l}\text { No. of People on the } \\
\text { Waiting List }\end{array}$ \\
\hline Deficiency anaemia & $\begin{array}{c}169 \\
(2.13 \%)\end{array}$ & $\begin{array}{c}\text { Pulmonary circulation } \\
\text { disorders }\end{array}$ & $\begin{array}{c}81 \\
(1.02 \%)\end{array}$ \\
\hline Type 1 Diabetes & $\begin{array}{c}104 \\
(1.31 \%)\end{array}$ & Psychoses & $\begin{array}{c}91 \\
(1.15 \%)\end{array}$ \\
\hline Type 2 Diabetes & $\begin{array}{c}1555 \\
(19.63 \%)\end{array}$ & $\begin{array}{l}\text { Peptic ulcer disease excluding } \\
\text { bleeding }\end{array}$ & $\begin{array}{c}52 \\
(0.66 \%)\end{array}$ \\
\hline Depression & $\begin{array}{c}613 \\
(7.74 \%)\end{array}$ & Peripheral vascular disorders & $\begin{array}{c}1335 \\
(16.85 \%)\end{array}$ \\
\hline Drug abuse & $\begin{array}{c}47 \\
(0.59 \%)\end{array}$ & Renal failure & $\begin{array}{c}422 \\
(5.33 \%)\end{array}$ \\
\hline Fluid and electrolyte disorders & $\begin{array}{c}176 \\
(2.22 \%)\end{array}$ & $\begin{array}{c}\text { Rheumatoid arthritis/ } \\
\text { collagen vascular diseases }\end{array}$ & $\begin{array}{c}460 \\
(5.81 \%)\end{array}$ \\
\hline AIDS/HIV & $\begin{array}{c}0 \\
(0.00 \%)\end{array}$ & Valvular disease & $\begin{array}{c}356 \\
(4.49 \%)\end{array}$ \\
\hline Hypothyroidism & $\begin{array}{c}809 \\
(10.21 \%)\end{array}$ & Weight loss & $\begin{array}{c}45 \\
(0.57 \%)\end{array}$ \\
\hline
\end{tabular}

\section{Discussion}

This study showed, for the first time, the incidence and characteristics of corneal grafts including information related to the type of surgery, medical indications, and correlation with DM in Poland, during 2013-2017. Until now, there have been no studies analyzing the epidemiologic indicators of $\mathrm{CT}$ based on the nationwide population from Central and Eastern Europe. The mean age of the study group was over 60 years, which could indicate the late diagnosis of corneal diseases in Poland [20-24].

The United States of America, with 19.91 transplants per one hundred thousand people, had the highest rate of CTs in the world. In Europe, the highest score was identified in The Netherlands and Switzerland, with about 8.80 per one hundred thousand people [5]. In Poland, the score was about 2.37 transplantations per one hundred thousand people in 2013 and this increased to 3.25 procedures per one hundred thousand in 2017. Compared to countries with a similar gross domestic product (GDP) per capita, such as the Czech Republic or Portugal, Poland still has a low value of both CT and eye banking [5]. Poland is a middle-income and relatively conservative Catholic country, which could be an important reason for a low number of CTs compared to other countries in Europe. However, a positive trend was observed-the number of CTs increased by $37 \%$ during the study period in Poland. This was a relatively high score when compared to trends in other European countries. For instance, in Germany there was only a $25 \%$ increase during the period 2012-2016 [22].

The indications for CT are different across countries and depend on the sociodemographic conditions of each population. In Poland, the main four indications accounting for $70 \%$ of CTs were ocular surface disease (38.51\%), bullous keratopathy $(13.53 \%)$, infectious keratitis and corneal ulcers (12.23\%), and keratoconus (8.68\%). In Germany [22], the most frequent indication for CTs was Fuchs endothelial corneal dystrophy (46\%), followed by bullous keratopathy and keratoconus. Similarly, in Great Britain, keratoconus (15\%), Fuchs endothelial corneal dystrophy $(9.3 \%)$, and bullus keratopathy $(7.6 \%)$ were the most often reported indications for CT [22,24].

During the study period, the general proportion of full-thickness and lamellar CTs was constant in Poland. In contrast, in a 10-year Canadian study, a significant decrease in the number of corneal transplants performed with penetrating keratoplasty had been observed [25]. Moreover, a Germany study revealed a shift from penetrating to lamellar 
procedures from 4\% in 2006 to $60 \%$ in 2016 as well [22]. The indications for full-thickness and lamellar transplantation also differed in Poland, i.e., $41.86 \%$ of all the full-thickness CTs was related to ocular surface disease, while the most frequent indication for lamellar CTs was bullous keratopathy (30.27\%).

Diabetes mellitus seems to have a meaningful impact on vision, mostly because of diabetic retinopathy and diabetic cataract [26]. At the same time, the cornea suffers from diabetic complications. According to Russian authors [27], up to 70\% of DM patients could be affected by corneal problems. The results of other previously published studies revealed that DM is considered a preoperative risk factor of graft failure [28]. In Poland, about $22 \%$ of the persons who underwent CT suffered from DM, which is three times more than the prevalence of DM in the Polish population [17]. The differences could be attributed to the age distribution of the study group. However, it was shown that the occurrence of DM was several times higher in the young age group within the study group than in the overall population. Meanwhile, the highest occurrence of both CT and DM refers to the oldest age group (over 30\% of the patients with CT were reported with DM in this group). DM occurrence differs between the indications for corneal graft in Poland. Relatively low values of the occurrence of DM were observed in the patients with keratoconus.

In Poland, CT may be performed as either an elective or urgent procedure in a hospital. Our analysis revealed that the chance of urgent surgery is mostly correlated with patient age, CT not combined with other procedures, and penetrating CT. The chance of urgent hospitalization is about two times higher for children compared to adults. That result is strongly correlated with the rules of the waiting list in Poland where children are on the priority list [6]. The chance of lamellar keratoplasty performed urgently is over 11 times lower than that of full-thickness CT. Other factors, including DM and sex, were revealed to be statistically non-significant in multiple regression analysis. Although the popularity of lamellar CT is rising worldwide, the procedure is more challenging and requires an experienced surgeon [29]. An analysis of comorbid factors among the persons on the waiting list for CT in Poland reveals 1.31\% of subjects with type $1 \mathrm{DM}$ and $19.63 \%$ with type $2 \mathrm{DM}$. This is a high score compared to DM prevalence in the overall Polish population but correlates with the age distribution of the patients on the waiting list. Furthermore, diseases related to depression and mental disorders could be highlighted. According to the Institute for Health Metrics and Evaluation [30], the prevalence of depression among the persons on the waiting list was over two times higher than in the general population in Poland.

The limitations of the present study include a lack of pathologic reports, laterality, and information of the number of anterior and posterior lamellar grafts in both the NHF and Poltransplant databases. Therefore, we were unable to recognize re-graft cases and investigate the potential risk factors of CT failures. However, this probably only had a minor impact on the study findings. Population size, national recruitment, and the impact of its findings on public healthcare policy are the most important strengths of the present study.

\section{Conclusions}

In conclusion, this study reported the incidence and characteristics of corneal transplantation in Poland during 2013-2017. Despite the relatively low value of both CT and eye banking in Poland, there was an increasing number of CTs in the analyzed period. However, the statistical analysis did not indicate DM as a significant factor of urgent CT, it was shown that about $23 \%$ of all CTs were performed on persons with DM. We believe this epidemiological study will help clinicians and healthcare institutions in Poland to better manage and treat patients with indications for CT.

Author Contributions: M.K. and M.S.N. conceived and designed the experiments. Data were collected by M.K. The results were analyzed by M.K., M.S.N., M.U. and J.P.S. The first and final drafts were written by M.K. The defects of the draft were reviewed by M.S.N. All authors have read and agreed to the published version of the manuscript. 
Funding: The present study was a part of the Polish Ministry of Health project "Maps of Healthcare Needs-Database of Systemic and Implementation Analyses" and was co-financed by the European Union funds through the European Social Fund under the Operational Program of Knowledge Education and Development (EU grant number: POWR 05.02.00-00-0149/15-01).

Institutional Review Board Statement: The study adhered to the tenets of the Declaration of Helsinki for research involving human subjects and the study protocol was approved by the Polish Ministry of Health, which is entitled by the law of the Republic of Poland to process the National Health Fund data.

Informed Consent Statement: Not applicable.

Data Availability Statement: The National Health Fund Registry data are available at http:// www.nfz.gov.pl (accessed on 10 August 2020), and the Statistics Poland data are available at http: //www.stat.gov.pl (accessed on 10 August 2020).

Conflicts of Interest: The authors declare no conflict of interest.

\section{Appendix A}

Table A1. Indications for CTs in Poland during 2013-2017.

\begin{tabular}{cc}
\hline Indication & Indication ICD-10 \\
\hline Ocular surface diseases & H18.8 \\
\hline Bullous keratopathy & $\mathrm{H} 18.1$ \\
\hline Infectious keratitis and corneal ulcers & $\mathrm{H} 16.0, \mathrm{H} 16.2, \mathrm{H} 16.3, \mathrm{H} 16.8, \mathrm{H} 16.9$ \\
\hline Keratoconus & $\mathrm{H} 17.8, \mathrm{H} 17.9, \mathrm{H} 17.1$ \\
\hline Leucoma and corneal scars & $\mathrm{H} 18.0$ \\
\hline Corneal pigmentations and deposits & $\mathrm{H} 18.5$ \\
\hline Band keal dystrophies incl. Fuchs's dystrophy & $\mathrm{H} 18.4$ \\
\hline Other & - \\
\hline
\end{tabular}

\section{Appendix B}

Table A2. Medical history of subjects waited for CTs in Poland during 2013-2017.

\begin{tabular}{ccc}
\hline & Comorbidity Variable & Comorbidity Group (ICD-10 Codes) \\
\hline 1 & AIDS/HIV & B20, B21, B22, B24 \\
\hline 2 & Alcohol abuse & F10, E52, G62.1, I42.6, K29.2, K70.0, K70.3, K70.9, T51, Z50.2, \\
Z71.4, Z72.1
\end{tabular}


Table A2. Cont.

\begin{tabular}{|c|c|c|}
\hline & Comorbidity Variable & Comorbidity Group (ICD-10 Codes) \\
\hline 11 & Diabetes, Type 2 & E11 confirmed with purchased medications \\
\hline 12 & Drug abuse & F11, F12, F13, F14, F15, F16, F18, F19, Z71.5, Z72.2 \\
\hline 13 & $\begin{array}{l}\text { Fluid and electrolyte } \\
\text { disorders }\end{array}$ & $\mathrm{E} 22.2, \mathrm{E} 86, \mathrm{E} 87$ \\
\hline 14 & Hypertension & I10, I11, I12, I13, I15 \\
\hline 15 & Hypothyroidism & E00, E01, E02, E03, E89.0 \\
\hline 16 & Liver disease & $\begin{array}{c}\text { B18, I85, I86.4, I98.2, K70, K71.1, K71.3-K71.5, K71.7, K72-K74, } \\
\text { K76.0, K76.2-K76.9, Z94.4 }\end{array}$ \\
\hline 17 & Lymphoma & C81, C82, C83, C84, C85, C88, C96, C90.0, C90.2 \\
\hline 18 & Metastatic cancer & $\mathrm{C} 77, \mathrm{C} 78, \mathrm{C} 79, \mathrm{C} 80$ \\
\hline 19 & Obesity & E66 \\
\hline 20 & Other neurological disorders & $\begin{array}{c}\text { G10-G13, G20-G22, G25.4, G25.5, G31.2, G31.8, G31.9, G32, } \\
\text { G35-G37, G40, G41, G93.1, G93.4, R47.0, R56 }\end{array}$ \\
\hline 21 & Paralysis & $\begin{array}{c}\text { G04.1, G11.4, G80.1, G80.2, G81, G82, G83.0, G83.1, G83.2, } \\
\text { G83.3, G83.4, G83.9 }\end{array}$ \\
\hline 22 & $\begin{array}{l}\text { Peptic ulcer disease excluding } \\
\text { bleeding }\end{array}$ & K25.7, K25.9, K26.7, K26.9, K27.7, K27.9, K28.7, K28.9 \\
\hline 23 & Peripheral vascular disorders & $\begin{array}{c}\text { I70, I71, I73.1, I73.8, I73.9, I77.1, I79.0, I79.2, K55.1, K55.8, K55.9, } \\
\text { K95.8, Z95.9 }\end{array}$ \\
\hline 24 & Psychoses & F20, F22, F23, F24, F25, F28, F29, F30.2, F31.2, F31.5 \\
\hline 25 & $\begin{array}{l}\text { Pulmonary circulation } \\
\text { disorders }\end{array}$ & I26, I27, I28.0, I28.8, I28.9 \\
\hline 26 & Renal failure & I12.0, I13.1, N18, N19, N25.0, Z49.0, Z49.1, Z49.2, Z94.0, Z99.2 \\
\hline 27 & $\begin{array}{c}\text { Rheumatoid } \\
\text { arthritis/collagen vascular } \\
\text { diseases }\end{array}$ & $\begin{array}{l}\text { L94.0, L94.1, L94.3, M05, M06, M08, M12.0, M12.3, M30, } \\
\text { M31.0-M31.3, M32-M35, M45, M46.1, M46.8, M46.9 }\end{array}$ \\
\hline 28 & $\begin{array}{l}\text { Solid tumor without } \\
\text { metastasis }\end{array}$ & C00-C26, C30-C34, C37-C41, C43, C45-C58, C60-C76, C97 \\
\hline 29 & Valvular disease & $\begin{array}{c}\text { A52.0, I05-I08, I09.1, I09.8, I34-I39, Q23.0-Q23.3, Z95.2, Z95.3, } \\
\text { Z95.4 }\end{array}$ \\
\hline 30 & Weight loss & E40-E46, R63.4, R64 \\
\hline
\end{tabular}

\section{References}

1. Resnikoff, S.; Pascolini, D.; Etya'Ale, D.; Kocur, I.; Pararajasegaram, R.; Pokharel, G.P.; Mariotti, S.P. Global data on visual impairment in the year 2002. Bull. World Health Organ. 2004, 82, 844-851. [PubMed]

2. World Health Organization. Global Initiative for the Elimination of Avoidable Blindness; Unpublished Document WHO/PBL/97.61/Rev 1; World Health Organization: Geneva, Switzerland, 1997.

3. Schwartz, E.C.; Huss, R.; Hopkins, A.; Dadjim, B.; Madjitoloum, P.; Henault, C.; Klauss, V. Blindness and visual impairment in a region endemic for onchocerciasis in the Central African Republic. Br. J. Ophthalmol. 1997, 81, 443-447. [CrossRef]

4. Pascolini, D.; Mariotti, S.P. Global estimates of visual impairment: 2010. Br. J. Ophthalmol. 2011, 96, 614-618. [CrossRef]

5. Gain, P.; Jullienne, R.; He, Z.; Aldossary, M.; Acquart, S.; Cognasse, F.; Thuret, G. Global Survey of Corneal Transplantation and Eye Banking. JAMA Ophthalmol. 2016, 134, 167-173. [CrossRef]

6. Grzybowski, A.; Patryn, R. Current state of corneal transplants in Poland. Acta Ophthalmol. 2017, 96, e93-e94. [CrossRef]

7. Zacharias, T.; Ferreira, N. Nutritional risk screening 2002 and ASA score predict mortality after elective liver resection for malignancy. Arch. Med. Sci. 2017, 13, 361-369. [CrossRef]

8. Budzyński, J.; Tojek, K.; Wustrau, B.; Czerniak, B.; Winiarski, P.; Korzycka-Wilińska, W.; Banaszkiewicz, Z. The “cholesterol paradox" among inpatients-retrospective analysis of medical documentation. Arch. Med. Sci. Atheroscler. Dis. 2018, 3, e46-e57. [CrossRef]

9. Chlebicki, A.; Kozioł, M. Homogeneous Group approach to Elixhauser comorbidity for hospital death using administrative data. Arch. Med. Sci. 2020, 16, 321-336. [CrossRef]

10. Elixhauser, A.; Steiner, C.; Harris, D.R.; Coffey, R.M. Comorbidity measures for use with administrative data. Med. Care 1998, 1, 8-27. [CrossRef] 
11. Ing, J.J.; Ing, H.H.; Nelson, L.R.; Hodge, D.O.; Bourne, W.M. Ten-year postoperative results of penetrating keratoplasty. Ophthalmology 1998, 105, 1855-1865. [CrossRef]

12. Wang, J.; Chen, K.; Li, X.; Jin, X.; An, P.; Fang, Y.; Mu, Y. Postoperative adverse events in patients with diabetes undergoing orthopedic and general surgery. Medicine 2019, 98, e15089. [CrossRef]

13. Świrska, J.; Czuczwar, P.; Zwolak, A.; Matyjaszek-Matuszek, B. Perioperative complications of gynecologic surgery in diabetic patients. Ginekol. Polska 2016, 87, 194-199. [CrossRef]

14. Huang, P.-Y.; Lin, M.-Z.; Wen, J.-P.; Li, X.-J.; Shi, X.-L.; Zhang, H.-J.; Chen, N.; Li, X.-Y.; Yang, S.-Y.; Chen, G. Correlation of early postoperative blood glucose levels with postoperative complications, hospital costs, and length of hospital stay in patients with gastrointestinal malignancies. Endocrine 2014, 48, 187-194. [CrossRef]

15. Nowak, M.S.; Grabska-Liberek, I.; Michalska-Małecka, K.; Grzybowski, A.; Kozioł, M.; Niemczyk, W.; Więckowska, B.; Szaflik, J.P. Incidence and Characteristics of Cataract Surgery in Poland, during 2010-2015. Int. J. Environ. Res. Public Health 2018, 15, 435. [CrossRef]

16. Nowak, M.S.; Grzybowski, A.; Michalska-Małecka, K.; Szaflik, J.P.; Kozioł, M.; Niemczyk, W.; Grabska-Liberek, I. Incidence and Characteristics of Endophthalmitis after Cataract Surgery in Poland, during 2010-2015. Int. J. Environ. Res. Public Health 2019, 16, 2188. [CrossRef]

17. Kozioł, M.; Nowak, M.S.; Udziela, M.; Piątkiewicz, P.; Grabska-Liberek, I.; Szaflik, J.P. First nation-wide study of diabetic retinopathy in Poland in the years 2013-2017. Acta Diabetol. 2020, 57, 1255-1264. [CrossRef]

18. National Health Fund Data. Available online: http:/ / www.nfz.gov.pl (accessed on 10 August 2020).

19. Central Statistical Office of Poland Data. Available online: http://www.stat.gov.pl (accessed on 10 August 2020).

20. Yu, A.; Schaumberger, M.; Kaiser, M.; Messmer, E.; Kook, D.; Welge-Lussen, U. Perioperative and postoperative risk factors for corneal graft failure. Clin. Ophthalmol. 2014, 8, 1641-1647. [CrossRef]

21. Dandona, L.; Naduvilath, T.; Janarthanan, M.; Ragu, K.; Rao, G.N. Survival analysis and visual outcome in a large series of corneal transplants in India. Br. J. Ophthalmol. 1997, 81, 726-731. [CrossRef]

22. Flockerzi, E.; Maier, P.; Böhringer, D.; Reinshagen, H.; Kruse, F.; Cursiefen, C.; Reinhard, T.; Geerling, G.; Torun, N.; Seitz, B. Trends in Corneal Transplantation from 2001 to 2016 in Germany: A Report of the DOG-Section Cornea and its Keratoplasty Registry. Am. J. Ophthalmol. 2018, 188, 91-98. [CrossRef]

23. Zeschau, A.; Balestrin, I.G.; Stock, R.A.; Bonamigo, E.L. Indications of keratoplasty: A retrospective study in a University Hospital. Rev. Bras. Oftalmol. 2013, 72, 316-320. [CrossRef]

24. Al-Yousuf, N.; Mavrikakis, I.; Daya, S.M. Penetrating keratoplasty: Indications over a 10 year period. Br. J. Ophthalmol. 2004, 88, 998-1001. [CrossRef]

25. Zhang, A.Q.; Rubenstein, D.; Price, A.J.; Côté, E.; Levitt, M.; Sharpen, L.; Slomovic, A. Evolving surgical techniques of and indications for corneal transplantation in Ontario: 2000-2012. Can. J. Ophthalmol. 2013, 48, 153-159. [CrossRef]

26. Ljubimov, A.V. Diabetic complications in the cornea. Vis. Res. 2017, 139, 138-152. [CrossRef]

27. Didenko, T.N.; Smoliakova, G.P.; Sorokin, E.L.; Egorov, V.V. Clinical and pathogenetic features of neurotrophic corneal disorders in diabetes. Vestn. Oftalmol. 2000, 115, 7-11.

28. Yu, A.L.; Kaiser, M.; Schaumberger, M.; Messmer, E.; Kook, D.; Welge-Lussen, U. Donor-Related Risk Factors and Preoperative Recipient-Related Risk Factors for Graft Failure. Cornea 2014, 33, 1149-1156. [CrossRef]

29. Watson, S.; Ramsay, A.; Dart, J.K.; Bunce, C.; Craig, E. Comparison of deep lamellar keratoplasty and penetrating keratoplasty in patients with keratoconus. Ophthalmology 2004, 111, 1676-1682. [CrossRef]

30. Institute for Health Metrics and Evaluation. Global Burden of Disease Study 2019. Available online: http://vizhub.healthdata. org/gbd-compare/ (accessed on 7 April 2021). 